\title{
TOMASZ SIKORSKI
}

\author{
Uniwersytet Szczeciński
}

\section{„Klatka Ezry”. Między poezją a polityką}

Kiedy w 1948 r. znany pisarz i krytyk Hugh Kenner, autor bestselleru The Pound Era (1971), odwiedził Ezrę Pounda w waszyngtońskim Szpitalu św. Elżbiety, był on banitą, szaleńcem zamkniętym w zakładzie psychiatrycznym z gwałcicielami, sadystami i dewiantami. Żył w hermetycznej pustce, w pokoju bez klamek, z zakratowanymi oknami. Snuł się po korytarzach, mijając co rusz „współlokatorów”, ubranych w plastikowe uniformy, z nogami spętanymi łańcuchami. Znajdował się w dantejskim czyśćcu. Pokutował za swoje przewiny, niepopularne poglądy, antysemityzm, za wspieranie włoskiego reżimu faszystowskiego. Można było wówczas przypuszczać, że jego czas już minął. Trwała przecież na dobre era Thomasa Eliota, który w tym samym roku otrzymał prestiżową literacką Nagrodę Nobla ${ }^{1}$.

Postać Ezry Pounda, wybitnego amerykańskiego poety, znana jest dziś chyba tylko wąskiemu gronu literaturoznawców, miłośników poezji, czy tłumaczy jego dzieł. Ciągle jednak dla wielu krytyków pełna wewnętrznych sprzeczności biografia Pounda przysłania jego wkład w literaturę (a zwłaszcza poezję) światową. Można odnieść wrażenie, że bywa niedoczytany do końca, jego dzieła studiowane są i analizowane we fragmentach, nie do końca, wyrywkowo.

$\mathrm{Z}$ jeszcze większą ignorancją, jeśli nie obojętnością do powikłanych, kontrowersyjnych losów Ezry Pounda podchodzą historycy. Ci, którzy kojarzą postać Pounda, umieszczają ją bez namysłu w jednym szeregu z Robertem Brasillachem²,

${ }^{1}$ H. Kenner, The Poetry of Ezra Pound, New York 1951; A. Arno, Błąd trubadura, http:// www.dwutygodnik.com/artykul/3088-blad-trubadura.html (dostęp: 20.09.2016).

2 Robert Brasillach (1909-1945) - francuski poeta, prozaik, dramaturg i krytyk literacki, współpracownik nacjonalistycznych pism „L'Action française” i „Je suis partout”. W 1945 r. został oskarżony o kolaborację z Niemcami i stracony w Fort Montrouge pod Paryżem. 
Louisem-Ferdinandem Céline ${ }^{3}$ i Pierre'em-Eugéne'em Drieu la Rochelle'em ${ }^{4}$. Dla nich pozostanie za zawsze „faszystowskim romantykiem" $i$ antysemitą.

Ezra Pound, a właściwie Ezra Weston Loomis Pound, urodził się w Hailey, w stanie Idaho, w 1885 r. Jego ojciec - Homer Pound — dziedziczył tam publiczne grunty (później pracował w mennicy), matka - Isabel, z domu Weston — zajmowała się domem. $Z$ jego rodziny (ze strony matki) wywodził się Henry Wadsworth Longfellow - poeta romantyczny. Zaś dziadek Pounda - Thaddeus - przez kilka lat zasiadał w amerykańskim kongresie, piastował też urząd zastępcy gubernatora stanu Wisconsin. Gdy Ezra miał niespełna dwa lata, jego rodzina przeniosła się do Nowego Yorku, aby nieco później, w 1889 r., na stałe osiąść w Wyncote, na przedmieściach Filadelfii. Uczęszczał do Cheltenham Military Academy i Cheltenham High School, aby w 1901 r. podjąć studia na uniwersytecie w Pensylwanii. Studia po dwóch latach przerwał i przeniósł się do Hamilton College w Clinton (w stanie Nowy York). Tam został bakałarzem filozofii, aby znów powrócić do Pensylwanii, gdzie w 1906 r. otrzymał tytuł magistra nauk humanistycznych (w dziedzinie literatur romańskich).

Pound nie był uczniem łatwym. Buntował się przeciwko akademickim rygorom, polemizował z uznanymi profesorami, domagał się „,czystości poezji”, zerwania z okowami naleciałości romantyczno-wiktoriańskich. Mając 15 lat, postanowił, że o poezji w wieku 30 lat będzie wiedział więcej niż ktokolwiek na świecie. Jego fascynacja średniowieczną literaturą prowansalską, hiszpańską i włoską, wówczas przecież zupełnie niemodną, napotykała na opór profesorskiej elity. Ezra, łamiąc uniwersyteckie reguły i program, wyczulony na akademickie maniery, miesiącami przesiadywał w bibliotece, wertując starodruki. Zaczytywał się w klasyce angielskiej, w dziełach Szekspira, studiował samodzielnie łacińskich poetów i hiszpański dramat. Już wówczas ugruntował swój pogląd o Dante Alighierim, co znalazło swój wyraz w opublikowanym pięć lat później (w 1910 r.) zbiorze esejów pt. Duch romański. Zagadnienia tam poruszane nie układały się w jedną całość. Refleksje nad literaturą prowansalską, średniowieczną, rzymską, czy iberyjską przeplatały się z zagadnieniami szczegółowymi, tworząc manifest literacki, który w przyszłości rezonował na europejski modernizm (np. Eliota i Becketta). W wieku XX dostrzegał te same refleksy upadku cywilizacji i kultury europejskiej, co u schyłku

${ }^{3}$ Louis-Ferdinand Céline (1894-1961) — francuski pisarz i eseista, prekursor egzystencjalizmu, zaciekły krytyk komunizmu, anarchizmu i rewolucji, głosił poglądy antysemickie. Po zakończeniu II wojny światowej oskarżany o faszyzm i kolaborację z Niemcami. Ostatnie lata życia spędził w zapomnieniu i samotności. Zmarł w Meudon, gdzie został pochowany.

${ }^{4}$ Pierre-Eugéne Drieu la Rochelle (1893-1945) — francuski prozaik, poeta, dramaturg i publicysta, współpracownik nacjonalistyczno-monarchistycznej Action Francaise oraz profaszystowskiej Francuskiej Partii Ludowej, redaktor pisma „L'Émancipation Nationale”. Oskarżany o kolaborację z Niemcami, w marcu 1945 r. popełnił samobójstwo (otruł się środkami nasennymi w amerykańskim szpitalu polowym). 
średniowiecza, stąd czuł pobratymstwo ze starowłoskimi trubadurami i największym spośród wszystkich mistrzów - Dantem ${ }^{5}$.

Ezra Pound był samoukiem, indywidualistą do szpiku kości, a zarazem człowiekiem o wielkiej dyscyplinie duchowej i samozaparciu. Swoje studia i gusta estetyczne (także krytyczne), które daleko wybiegały poza literacki widnokrąg szlifował sam. Nauczył się lepiej lub gorzej władać kilkoma językami: starofrancuskim, francuskim, włoskim, hiszpańskim, greką, łaciną, prowansalskim i anglosaksońskim (staroangielskim). Interesowała go sztuka, malarstwo i rzeźba oraz muzyka operowa. Wśród znajomych chwalił się, że ma również talent stolarski i sam wyrabia meble. Jego przyjaciel i współlokator z domu akademickiego, późniejszy znany poeta (z zawodu lekarz) William Carlos Williams, wspominał Ezrę jako człowieka nieprzeciętnie zdolnego, błyskotliwego, pełnego niespożytej energii, ale zarazem powszechnie nielubianego. Zrażał do siebie ludzi megalomanią, błazeństwem i pozerstwem; jednocześnie oczekiwał uznania i poklasku. Najprawdopodobniej właśnie skrajnie indywidualistyczne usposobienie Pounda i jeszcze wówczas nieco stępiona narcystyczna „mania wyższości” uniemożliwiły mu zrobienie doktoratu. Wspominał po latach, że jego niedoszły promotor odrzucił pomysł dysertacji poświęconej literaturze prowansalskiej, nieujętej w programie nauczania, bo musiałby się nad tym napracować. Jeśli nawet tak nie było, to autor Ducha romańskiego nie ukrywał, że na temat poezji staroprowansalskiej wie więcej aniżeli jego nauczyciele ${ }^{6}$.

Po ukończeniu studiów Ezra Pound krótko wykładał w Wabash College w Crawfordsville (1907-1908), aby później opuścić Amerykę i wyjechać do Europy. W lutym 1908 r., mając przy sobie niewielką sumę pieniędzy, popłynął najpierw na Gibraltar, a stamtąd do Wenecji. Żył tam jak kloszard, karmiony smażonymi skrawkami ziemniaków przez targowe przekupy i straganiarki. Biedowanie go jednak nie załamało, a wręcz odwrotnie - mobilizowało go do twórczego działania. To właśnie w Wenecji Pound zdecydował, że wejdzie taranem na literackie salony. Własnym sumptem wydał pierwszy tomik poezji A lume spento, świadomie zaczerpując tytuł z Dantego. Niewielki nakład rozsyłał do znajomych, redaktorów pism kulturalnych i krytyków. Początkowo nic jednak nie zapowiadało kariery, o jakiej marzył.

5 L. Engelking, Owoc młodzieńczej miłości, [w:] E. Pound, Duch romański, Warszawa 1999, s. $261-264$.

${ }^{6}$ Na podstawie P. Morrison, The Poetics of Fascism. Ezra Pound, Thomas S. Eliot, Paul de Mann, Oxford 1996; A.D. Moody, Ezra Pound Poet: A Portrait of the Man and His Work, t. II. The Epic Years 1921-1939, Oxford 2014; idem, op. cit., t. III. The Epic Years 1939-1972, Oxford 2015; P. Brody, Exspatriate. A Biography of Ezra Pound, Oxford 2014; E.C. Mullins Jr., This Difficult Individual: Ezra Pound, Los Angeles 1961; W. Schmied, Ezra Pound: ein Leben zwischen Kunst und Politik. Essays, Innsbruck 1994; Ch. Norman, Ezra Pound, New York 1960; G.S. Fraser, Ezra Pound, London 1960; L. Engelking, Kalendarium życia i twórczości Ezry Pounda, „Literatura na Świecie" 1985, nr 1, s. 185-188. 
We wrześniu 1908 r. Pound opuścił Włochy i udał się do Londynu, gdzie mieszkał aż do 1920 r., odwiedzając jeszcze kilkakrotnie Półwysep Apeniński, Francję, Niemcy i rodzinną Amerykę. W Londynie zadomowił się dość szybko, choć znów — przynajmniej na początku — biedował. Zaprzyjaźnił się z pisarzem i wydawcą Fordem Madoxem Fordem oraz uznanym już wówczas irlandzkim poetą Williamem Butlerem Yeatsem. Dzięki niemu poznał również Olivię Shakespear i jej córkę, śliczną Dorothy, „o porcelanowej twarzy”, która wkrótce została jego żoną.

Nowe znajomości otworzyły przed Poundem także nowe możliwości. Szybko zaadoptował się w londyńskiej bohemie artystycznej, uczestniczył w dyskusjach na temat poezji i sztuki. Na spotkaniach organizowanych w literackich salonach głosił swoje poglądy z przekonaniem i energią. Wiosną 1909 r. zakotwiczył się w „Secession Club”, przyłączając się do grupy poetów (wśród których byli np. Thomas Ernest Hulme, Frank Stuart Flint), spotykających się w Eiffel Tower Restaurant, w londyńskim Soho.

Na spotkaniach [...] mówiono [...] o sytuacji literatur anglosaskich, twórczości francuskich symbolistów, zagadnieniach związanych z wolnym wierszem, poezji biblijnej i dziełach trubadurów. Jak się zdaje, centralną postacią był na tych spotkaniach Hulme, który kładł nacisk na konieczność wyzbycia się przez poetów wielomowności i znajdowania dla każdej rzeczy le mot juste oraz na obiektywną beznamiętną prezentację ${ }^{7}$.

W rozlicznych recenzjach, tekstach krytycznoliterackich i kolejno wydanych tomikach wierszy: Personae (1909), Exultations (1909), Provenca (1910) i Canzoni (1911) Ezra Pound konsekwentnie ,oczyszczał” piórem poezję z romantyczno-wiktoriańskich naleciałości i sentymentalizmu ${ }^{8}$. Nowoczesnej formie przeciwstawiał wiersz zespolony z muzycznym rytmem, charakterystycznym dla pieśni średniowiecznych trubadurów. W epoce cywilizacyjnej zapaści poszukiwał prostoty języka i potocznych rytmów. Wkrótce ten ,program poetycki” przyniesie mu sławę?

7 L. Engelking, Ezra Pound, „Literatura na Świecie” 1985, nr 1, s. 311.

8 T.S. Eliot, Ze wstepu do „Poezji wybranych” Ezry Pounda [1928], „Literatura na Świecie” 1985, nr 1, s. 41-46; E. Pound, Rzut oka za siebie, przeł. L. Engelking, ibidem, s. 3-17; T.S. Eliot, Ze wstęu do tomu ,Literary Esseys of Ezra Pound” [1954], przeł. L. Engelking, ibidem, s. 27-28; H. Curruth, Poezja Ezry Pounda, przeł. Z. Bohdanowicz, „Tematy” 1962, nr 2, s. 78-109; P. Russel, Ezra Pound, przeł. M. Niemojewska, „Poezja” 1970, nr 3, s. 60-65; A. Baranowska, Ezra Pound (30 X 1885 - 1 IX 1972), „Twórczość” 1973, nr 4, s. 155-157; Ł. Wróbel, Stowa i obrazy. O poezji Ezry Pounda, „Kultura Liberalna” 2012, nr 194, http://kulturaliberalna.pl/2012/09/25/wrobel-slowa-i-obrazy-o-poezji-ezry-pounda/ (dostęp: 20.09.2016); W. Pietrzak, Poezja życia / poezja instrukcji: poems Andrzeja Sosnowskiego w kontekście teorii poezji Ezry Pounda, „Poznańskie Studia Polonistyczne: Seria Literacka" 2013, nr 42, s. 251-268.

9 K. Iłłakowiczówna (K.I.), Ezra Pound, „Poezja” 1968, nr 12, s. 105. 
W 1912 r. Ezra Pound uporządkował swoje poglądy i opublikował tzw. manifest imagizmu, który zrewiduje, a raczej należałoby powiedzieć zrewolucjonizuje poezję angielską ${ }^{10}$.

Do środowiska imaginistów należeli jeszcze: Hilda Doolittle, Richard Aldington, William Carlos Williams, Frank Stuart Flint, nieco później również: Amy Lowell, John Cournos i Allen Upward. Po kilku latach ruch imagizmu powoli zamiera. Sam Ezra Pound już w 1914 r. uważał się za "pełnokrwistego” wortycystę ${ }^{11}$, choć w swojej twórczości łączył oba nurty ${ }^{12}$.

Imagistyczne i wortystyczne refleksy programowe i wiersze Pounda weszły jeszcze do tomiku Ripostes, zamieszczono je również w piśmie rzeczników wortycyzmu „Blast” oraz w tekstach opublikowanych na łamach chicagowskiego „Poetry”. Nie sposób także pominąć Hołdu dla Sekstusa Propercjusza (Homage to Sextus Propertius) z 1919 r., który można usytuować między klasycznym tłumaczeniem (niestety pełnym nieścisłości translatorskich) a utworem oryginalnym, który Eliot nazwał „parafrazą” oryginału. Innym kluczowym dla poezji XX w. utworem był Hugh Selwyn Mauberley (1920), którym Pound żegnał się z Londynem ${ }^{13}$.

Pracę twórczą Pound łączył z podróżami. Odwiedzał Francję, gościł w stolicy, przemierzył pieszo całą Prowansję, kilkakrotnie powracał również do Stanów Zjednoczonych. Pound jest już wówczas znanym i rozpoznawalnym poetą, także dzięki ekstrawaganckiemu sposobowi bycia. Prawdą jest, że nosił się dość odważnie. Chadzał w zielonych przykrótkich spodniach z grubego sukna służącego do wykładania stołów bilardowych, przydługiej koszuli, wysokich skórzanych butach,

10 Zasady imaginizmu Pound streszczał w trzech punktach: 1) Należy bezpośrednio traktować „rzeczy” zarówno subiektywne, jak i obiektywne; 2) Należy bezwzględnie rezygnować z każdego słowa, które nie przyczynia się do prezentacji; 3) Co się tyczy rytmu, należy komponować w zgodzie z frazą muzyczną, a nie taktem metronomu. Por. szerzej: F.S. Flint, E. Pound, Imagisme, przeł. L. Engelking, „Literatura na Świecie” 1991, nr 1, s. 170-175; L. Engelking, Imagizm, ibidem, s. 190-209; E. Pound, Rzut oka za siebie, „Literatura na Świecie” 1985, nr 1, s. 3; P. Jones, Introduction, [w:] Imagist Poetry, red. P. Jones, Harmondswort 1976, s. 7 n.; A. Hutnikiewicz, Od czystej formy do literatury faktu, Torun 1965, rozdział V, s. 121-124; S. Wącior, Modernist Mutations The Morphology of the Imagist Poem: Context - Text - Intertext, Lublin 2003.

11 Wortycyzm (łac. vortex — „zawirowanie”, „wir”, „,burza”) był awangardowym ruchem artystycznym, zrzeszającym plastyków (malarzy i rzeźbiarzy) i poetów, postulującym odejście od sztuki abstrakcyjnej; kładł nacisk na autonomię dzieła sztuki i wiersza, sprzeciwiał się realistycznemu ukazywaniu świata. W poezji „obraz” miał być tożsamy z „wirem” (słowa są tożsame z obrazami), przez który strumieniem płyną idee. Por. E. Pound, Wortycyzm (fragment), przeł. L. Engelking, „Literatura na Świecie” 1991, nr 1, s. 176-189.

12 Por. S. Helsztyński, Wprowadzenie do Ezry Pounda, [w:] idem, Od Chaucera do Ezry Pounda, Warszawa 1976, s. 171-187; L. Engelking, Maski Ezry Pounda, „Literatura na Świecie” 1980, nr 4, s. 304-309.

13 Por. Z. Kubiak, Dialog Eliota z Poundem, „Tygodnik Powszechny” 1973, nr 21, s. 4; L. Engelking, Posłowie, [w:] E. Pound, Wiersze, poematy i pieśni, przeł. L. Engelking, Wrocław 2012, s. 221-225. 
z kolczykiem w uchu. Przykuwał uwagę także swoim zachowaniem, nieco nonszalanckim i błazeńskim, z którego jednocześnie przebijała szaleńcza, nieokiełznana energia.

W tym czasie poszerzał się również krąg przyjaciół i znajomych Ezry Pounda. Zaliczyć do nich można przedwcześnie zmarkego rzeźbiarza Henri Gaudiera-Brzeskę, któremu później Pound poświęca książkę - kolaż na temat współczesnej sztuki (Gaudier-Brzeska. A Memoir [1916]) ${ }^{14}$, Williama Butlera Yeatsa (przez niespełna rok był jego osobistym sekretarzem), Roberta Frosta, Thomasa Eliota, któremu pomaga przebić się „na salony”15. Utrzymywał też korespondencyjny kontakt z Jamesem Joyce'em, a potem stał się jego mecenasem $^{16}$. W 1913 r., w momencie zbliżenia się do ruchu imaginistów, Pound poznał wdowę po Erneście Fenellosie - orientaliście, filozofie, profesorze uniwersytetu w Tokio. Otrzymał od niej notatniki po zmarłym uczonym. Zawierały one m.in. przekłady japońskich sztuk teatralnych i wierszy poetów chińskich. Pound interesował się literaturami Dalekiego Wschodu, sięgał do Konfucjusza, którego przetłumaczył na język angielski i włoski ${ }^{17}$.

Najprawdopodobniej po raz pierwszy ze światem haiku (japońska forma poetycka) ${ }^{18}$ i literatury chińskiej Pound zetknął się podczas spotkań w Klubie Secesji. Tam właśnie Flint i Hulme (najczęściej właśnie oni) dyskutowali na temat japońskiej i chińskiej tradycji literackiej. W każdym razie „podobnie jak XVII-wieczni poeci japońscy, Pound wspaniale potrafił oddać ulotny nastrój, smak mijającej chwili, subtelny odcień wzruszenia. Przypomnijmy choćby takie wiersze jak Na stacji metra (In a Station of the Metro), Alba i Ekspedientka (Shop Girl), wszystkie z tomu Lustra, czy Erat hora z wcześniejszego tomu Canzoni"19.

Rozpoczynał się „nowy” etap w twórczości Ezry Pounda. Zafascynowany tradycją Orientu pogłębiał wiedzę na temat literatury chińskiej i japońskiej, sięgając choćby do Historii literatury chińskiej pióra Herberta Gillesa. Te inspiracje przyniosły dość szybko pierwsze próbki liryczne, a następnie edycję wierszy chińskich (w thumaczeniu Pounda) pt. Cathay. Pound przetłumaczył też esej Fenollosy

14 Por. szerzej M. Perloff, Gaudier-Brzeska. Ezry Pounda portret artysty jako tekst - kolaż, „Literatura na Świecie” 1985, nr 1, s. 143-167; E. Pound, Sztuka, maszyny i inne pisma, przeł. E. Mikina, Warszawa 2003, s. 119-121.

15 Por. K. Szymańska, Ezra Pound o wielu twarzach, „Literatki”, 28.06.2012 r., http://literatki. com/6566/ezra-pound-wiersze-poematy-i-piesni-ezra-pound-o-wielu-twarzach (dostęp: 20.09.2016); D. Hall, Wywiad z Ezra Poundem, „Literatura na Świecie” 1985, nr 1, s. 209.

16 Por. A. Baranowska, Historia pewnego mecenatu, „Twórczość” 1968, nr 7, s. 185-187.

17 Por. szerzej E. Miner, Pound, haiku i obraz poetycki, przeł. L. Engelking, „Literatura na Świecie” 1985, nr 1, s. 98-123; L. Engelking, Ezra Pound, „Literatura na Świecie” 1985, nr 1, s. 306-307; I. Łąbędzka, Chiny Ezry Pounda, Poznań 1998, s. 181. Na temat Fenollosy pisali: W. van Brooks, Fenollosa and His Circle, with Other Essays in Biography, New York 1962; L.W. Chisolm, Fenollosa: the Far East and American Culture, New Haven 1963.

18 K. Sato, Czy można przesadzić kwiat rzepaku? (Japońskie haiku i ruch haiku na Zachodzie), przeł. A Szuba, „Literatura na Świecie” 1991, nr 1, s. 210-217.

19 L. Engelking, Ezra Pound..., s. 306. 
pt. Znak pisma chińskiego jako środek poetycki (The Chinese Written Character as a Medium for Poetry). Zwróciły wówczas jego uwagę chińskie ideogramy. Tak zwana „metoda ideograficzna” — wyjaśnia Leszek Engelking — „polega na »zestawieniu i zderzaniu ze sobą« różnych faktów, dokumentów, cytatów, mitów, legend itd. $\mathrm{Z}$ takiego zestawienia za każdym razem wynikać miała nowa jakość, podobnie jak z połączenia ideogramów, z których każdy oznacza jakąś rzecz, wynika całkiem nowe pojęcie"20. Zastosowanie metody ideograficznej znalazło swój najpełniejszy wyraz w pisanych przez Pounda od 1917 r. Pieśniach (The Cantos). Pieśni pozornie przypominają niespójną całość składającą się z fragmentarycznych całostek. Rozmaite momenty i zespoły tematyczne przeplatają się tam z wątkami autobiograficznymi, kulturowymi i historycznymi. Na przykład The Malatesta Cantos VIII-XI - poświęcona Sigismundo Malateście, późnośredniowiecznemu władcy Rimini i mecenasowi sztuki; czy The Hell Cantos XIV-XV, The Chinese Cantos LIII-LXI — poświęcone historii Chin. Bohaterami (w zamyśle Pounda pozytywnymi) Cantos są również: John Adams i jego ród, Napoleon Bonaparte, Konfucjusz, Thomas Jefferson, czy Benito Mussolini ${ }^{21}$.

W Pieśniach, jak w żadnych innych utworach Pounda, wyczuwalne są impulsy jego poglądów i koncepcji politycznych. Już w latach londyńskich Ezra Pound zaczął interesować się polityką i ekonomią ${ }^{22}$. Gardził liberalizmem i chłodnym amerykańskim kapitalizmem, ale wobec demokracji jeszcze wówczas pozostawał obojętny. Uważał, że przyczyną wszelkich kryzysów jest z jednej strony brak autorytetu władzy, z drugiej kult pieniądza i rządy światowej finansjery (bankierów). Dziki kapitalizm doprowadził do nędzy i biedy, niesprawiedliwości, pauperyzacji i stratyfikacji społecznej. Rozwój nowoczesnych technologii i powszechne uprzemysłowienie - przekonywał Pound - doprowadziły do wzrostu pozycji banków, które obracały długami (wysoko oprocentowanymi kredytami), co nie przełożyło się na ogólny dobrobyt. Historiozofia Pounda — jak słusznie zauważył Tadeusz Pióro - zainspirowana została przez teorię Brooksa Adamsa o cyklicznych wzlotach i upadkach kultur i cywilizacji ${ }^{23}$. Przyczyną upadku był,

20 Ibidem, s. 309. Zob. również A. Sosnowski, Z genealogii modernizmu: poezja trzeciego nieba, „Literatura na Świecie” 1995, nr 1-2, s. 247-249.

21 Por. szerzej M.L. Rosenthal, Pieśni Ezry Pounda, przeł. A. Sylwanowicz, „Literatura na Świecie" 1985, nr 1, s. 265-273; M. Butor, Poetycka próba Ezry Pounda, ibidem, s. 280-297; H. Kenner, Niejasność, przeł. A. Zapałowski, „Literatura na Świecie” 1995, nr 1-2, s. 65-73; A. Sosnowski, Z genealogii modernizmu: poezja trzeciego nieba, ibidem, s. 234-254; A. Sosnowski, Posłowie, [w:] E. Pound, Pieśni, przeł. L. Engelking, K. Kozioł, A. Sosnowski, A. Szuba, Warszawa 1996, s. 176-183; P. Marcinkiewicz, Mitosz a amerykańska awangarda: od Pounda do Ashbery'ego, „Przekładaniec” 2011, nr 25, s. 126-129.

22 Wśród najważniejszych książek i broszur Ezry Pounda poruszających zagadnienia społeczne, ekonomiczne i polityczne wymienić należy: ABC ekonomii (1933), Jefferson i/lub Mussolini (1945), Po co sa pieniadze? (1939), Ameryka, Roosevelt i przyczyny obecnej wojny (1944), Złoto i praca (1944).

23 Por. T. Pióro, Przewodnik po Poundzie, „Literatura na Świecie” 1995, nr 1-2, s. 137. 
w opinii autora Pieśni, zachwiany system monetarny, błędne pojmowanie funkcji pieniądza oraz brak kontroli państwa nad bankami.

Poszukując jakiegoś remedium na cywilizacyjną zapaść, Pound sięgnął do coraz bardziej popularnych, ,alternatywnych” teorii ekonomicznych Clifforda Hugh Douglasa (1879-1952), pioniera tzw. kredytu społecznego. Douglas początkowo pracował jako inżynier w firmach elektrycznych i przedsiębiorstwach przewozów kolejowych, wykładał też w Stockport Gimnazjum. W wieku ponad 30 lat ukończył prestiżowy uniwersytet w Cambridge i podjął pracę w kompaniach (korporacjach) brytyjskich, m.in. w Indiach. Douglas zauważył wówczas, że klasyczne teorie liberalne prowadzą do wyzysku i niesprawiedliwości społecznej. Alternatywę dostrzegał w połączeniu postępowych idei chrześcijańskich z zastosowaniem metod inżynierii w ekonomii. Douglas miesiącami zbierał dane z ponad 100 największych firm brytyjskich i doszedł do wniosku, że przedsiębiorstwa te wkrótce zbankrutują, a kwoty wypłacane pracownikom z uposażeń i dywidend były zawsze niższe od łącznych kosztów towarów i usług. Podstawą koncepcji reform Douglasa, znanych pod nazwą tzw. kredytu społecznego, było założenie, że bogactwo społeczeństw pochodzi nie tylko z obecnych zakładów pracy, lecz także z dorobku poprzednich pokoleń. Stąd Douglas postulował upowszechnienie bogactwa i własności. Po drugie pieniądz nie miał być celem samym w sobie, ale miał służyć społeczeństwu. Douglas, jako domorosły ekonomista „naturszczyk”, dostrzegał, że wartość wytwarzanych dóbr jest większa od sumy uposażeń pracowników, którzy te dobra wytwarzają. Prowadziło to w konsekwencji do zadłużania się, a w następstwie do zaciągania kredytów w bankach. W szerszej perspektywie prowadzić mogło do ekonomicznego kryzysy państwa, ponieważ rząd, cierpiąc na chroniczny brak pieniędzy, zapożyczał się w bankach. W efekcie rosło zadłużenie państwa. Douglas proponował zatem wprowadzenie dywidendy społecznej, tak aby całkowicie darowana społeczeństwu kwota równała się sumie cen wytworzonych dóbr. W sumie więc chodziło o to, aby wszystko, co zostało wytworzone, mogło być kupione przez wszystkich. W ten sposób każdy obywatel-pracownik czerpałby z dziedzictwa minionych pokoleń. System kredytu społecznego przekreślałby także istnienie pensji, czyli jednorazowego wynagrodzenia za pracę (za wytworzone dobra). Zastąpiłaby ją dywidenda, co miało wyrównywać niesprawiedliwość i okiełznać antyspołeczne skutki dzikiego kapitalizmu. Biorąc pod uwagę postęp technologiczny, zachodzące procesy globalizacyjne (kapitalizm światowy), a tym samym słabnącą siłę roboczą, program Douglasa oprócz założeń stricte ekonomicznych musiał zawierać również przesłanki społeczne. Mianowicie „nowa formuła” rozliczeń miała mobilizować do pracy, a zarazem ograniczać wykluczenie społeczne ${ }^{24}$.

24 Por. szerzej J. Martin-Nielsen, An Engineer's View of an Ideal Society: The Economic Reforms of C.H. Douglas (1916-1920), „Spontaneous Generations” 1, 2007, s. 95-109. Zob. również K. Bolton, Ezra Pound, http://xportal.pl/?p=6804 (dostęp: 18.09.2016); Waluty, Pracy i dyskwalifi- 
Nie sposób nie dostrzec także wpływów na ekonomikę Pounda poglądów Jeana Silvio Gesella, niemieckiego teoretyka ekonomii, twórcy koncepcji tzw. Naturalnego Porządku Ekonomicznego. Sam Gasell był postacią równie ciekawą jak Douglas. Przez wiele lat pracował jako urzędnik pocztowy, handlowiec i korespondent prasowy w hiszpańskiej Maladze. Krótko po zakończeniu I wojny światowej, kiedy na terenie pobitej Rzeszy powstawały „republiki radzieckie”, Gesell zaangażował się po stronie komunistów i został nawet ministrem skarbu w Bawarskiej Republice Radzieckiej. Niespełna tydzień później został aresztowany, oskarżony o zdradę, a po kilku miesiącach uniewinniony i wypuszczony na wolność.

Teoria Naturalnego Porządku Ekonomicznego, w dużej mierze wywiedziona ze średniowiecznej praktyki, zakładała, że pieniądz powinien tracić na wartości (jak Gessel to określał — „rdzewieć”, „zużywać się”), a zatem tracić „naturalną” przewagę nad pracą ludzką i jej wytworami, czyli towarami. To pieniądz powinien służyć człowiekowi, a nie człowiek pieniądzowi — twierdził niemiecki ekonomista. Przywrócenie wartości „,początkowej” pieniądza miało nastąpić za pomocą tzw. opłaty dewaluacyjnej, która z jednej strony zapewniała obieg pieniądza, z drugiej hamowała kumulację kapitału i pieniądza przez jednostki. Tak skonstruowany system monetarny sprawiłby, że „prawdziwy pieniądz” byłby środkiem wymiennym i służył dobru wspólnemu. Poprzez regulację ilości pieniądza na rynku przekonywał Gesell - ceny utrzymywałyby się na stałym poziomie, przestarzałe towary pod naporem innowacji zniknęłyby z rynku, a niepokoje społeczne i bezrobocie zostałoby ograniczone do niezbędnego minimum ${ }^{25}$.

Ezra Pound rozumiał i korzystał z koncepcji Douglasa i Gesella nie w sposób kompleksowy, ale selektywny. Daleki był od ślepego, bezkrytycznego epigoństwa. Przywdziewając szaty poety doctusa, co oczywiste żegluje między czystością poezji, za którą się opowiada konsekwentnie, a koncentracją na przesłaniu ideowym, nachylając się ku światu politycznemu. Daje temu wyraz głównie w Pieśniach, gdzie jego impulsy społeczno-polityczne widać chyba najbardziej. Jeśli Pieśni przyjąć za poemat epicki, to - jak thumaczył sam Pound: „epos to poemat mówiący o historii. Nie przypuszczam, by ktokolwiek poza zupełnymi jełopami mógł dziś myśleć, że wie coś o historii, jeśli nie rozumie ekonomii” 26 . Ale do rzeczy — dla Ezry Pounda punktem wyjścia jest założenie, iż ekonomia powinna przede wszystkim pełnić rolę służebną wobec społeczeństwa. Swoją nieco zaszyfrowaną, wypełnioną rozlicznymi kontekstami, odniesieniami, mnóstwem dygresji i metafor - wizję stosunków społeczno-ekonomicznych zbudował więc na niepełnej syntezie teorii Douglasa i scholastycznej (średniowiecznej) wykładni ekonomii i pracy. Przyjrzyjmy się temu bliżej. Analogicznie do myśli

kacja (Ezra Pound), http://thule-italia.com/wordpress/valuta-lavoro-e-decadenze-ezra-pound-primaparte/?lang=pl (dostęp: 16.12.2016).

25 Warto nadmienić że teoria Naturalnego Porządku Ekonomicznego J.S. Gessela została wdrożona w praktyce (już po jego śmierci) w tyrolskiej gminie Wörgl z pełnym sukcesem.

26 L. Engelking, Ezra Pound..., s. 315. 
Akwinaty, Pound uznaje własność prywatną za element porządku społecznego, z co najmniej dwóch powodów. Po pierwsze przyczynia się ona do większej pracowitości ludzi, a po drugie - aby zapobiec chaosowi - umacnia porządek i hierarchie. Tyle tylko, że Pound, nawiązując do XIX-wiecznego socjalizmu chrześcijańskiego, domaga się uspołecznienia własności i rezygnacji z akumulacji (zgromadzenie nadwyżki poza tym co niezbędne) dla pożytku społecznego. Nieco mniej zrozumiałe, a może niedopowiedziane są natomiast $\mathrm{u}$ autora Cantos relacje między gromadzeniem a wydatkowaniem. Używając fizjologicznych metafor, Pound zakłada, że pieniądz pełni rolę „separatora”, zaś wysoko oprocentowany kredyt (lichwa) tamuje prawidłowy obieg pieniądza i towarów na rynku. W imię zasady sprawiedliwości należało więc utrzymać równowagę między ,siłą wyrzucającą" a „siłą powstrzymującą”. Pieniądz jest zatem tylko i wyłącznie pośrednikiem pomiędzy nabywcą a sprzedawcą 27 . Richard Sieburth pisze:

\begin{abstract}
„Lichwę” [...] poeta zwykle przedstawia jako chorobę układu trawiennego, toczącą ciało państwa. Prowadzi ona do rozległego zaparcia (tj. zapchania lub uniemożliwienia obiegu) lub do niepowstrzymanej biegunki (czego przykładem są kałuże łajna lub ciekłego złota, w których nurzają się bankierzy i finansiści w Pieśniach piekielnych). Pound utożsamia malwersacje gospodarcze i fałszowanie pieniądza z niewydolnością jelit, nawiązuje do Dantego, ponieważ wytwarzanie monet (wymagające stopienia i oczyszczania złota) kojarzy się tradycyjnie z trawieniem czy też „ulegiwaniem” jedzenia w żołądku. [...] Podejście, jakie Pound przyjmuje wobec lichwy, jest średniowieczne, również według niego lichwiarskie nadużycie powoduje nabrzmienie, wzdęcie i stwardnienie reprezentacji ekonomicznej i artystycznej. Pound często przedstawia „lichwę” jako obsceniczne wchłanianie i zatrzymywanie odchodów; równie często jednak opisuje spisek i jego żydowskich uczestników w kategorii ukrytej trucizny lub raka, niszczącego od wewnątrz tkankę państwa. W obu przypadkach zło, które Pound nazywa „lichwą" (lub w sposób już niewybaczalny — „żydłactwo”), jest obcym, pasożytniczym tworem kojarzonym z trzewiami, czymś miękkim, oślizłym, wężowatym i zakaźnym — czymś, co trzeba usunąć z organizmu, aby przywrócić prawidłowe trawienie ${ }^{28}$.
\end{abstract}

Ezra Pound dopuszczał, zapewne idąc śladami Douglasa, stosowanie innych niż bita moneta środków płatniczych, sprzyjając tzw. pluralizmowi monetarnemu albo zastąpieniu pieniądza środkiem zastępczym - np. dywidendą. Dla Pounda idealną formą wymiany był barter, eliminujący nieuczciwych, złych pośredników, w domyśle bankierów i lichwiarzy, którzy sztucznie sterują podażą i wartością znajdującego się w obiegu pieniądza. Podążając tropem średniowiecznej wykładni stosunków społeczno-ekonomicznych, Pound proponował, aby sprawiedliwa wymiana opierała się na wymianie ekwiwalentów, równości tego, co się daje, z tym, co się otrzymuje, bez szkody dla jednej i drugiej strony,

27 Por. D. Hall, Wywiad z Ezra Poundem, „Literatura na Świecie” 1985, nr 1, s. 217-218.

28 R. Sieburth, Ezra Pound: Ekonomia poezji / Poezja ekonomii, „Literatura na Świecie” 1995, nr 1-2, s. 296-297; T. Pióro, Przewodnik po Poundzie..., s. 137-139; R. Mozgol, Nie burzycielami być, lecz ludźmi. Poezja Ezry Pounda, „Zawsze Wierni” 2002, nr 2 (45), http://www. nacjonalista.p1/2014/04/01/ryszard-mozgol-nie-burzycielami-byc-lecz-ludzmi-poezja-ezry-pounda/ (dostęp: 1.06.2017). 
tj. dla sprzedającego i kupującego. Ta zasada równości wyrosła na gruncie średniowiecznej gospodarki cechowej, w której drobni wytwórcy (rzemieślnicy) znali koszty swoich materiałów oraz nakład pracy i potrafili w przybliżony sposób określić faktyczną cenę towaru. Pomimo iż Pound wywodził swoje poglądy z chrześcijaństwa, pozostawał wobec współczesnego jemu Kościoła krytyczny, czemu dał wyraz nie tylko w Pieśniach, ale przede wszystkim w Przewodniku po kulturze. Możemy tam przeczytać: „Schyłek Kościoła jako siły społecznej nastąpił wtedy, kiedy jego hierarchia straciła wiarę we własne dogmaty [...]. Kto pragnie uporządkować swoje myśli, powinien zanurzyć się na tydzień w choć jednej z dziedzin średniowiecznej scholastyki" ${ }^{29}$. Tak więc na pewno Pound nie był integrystą katolickim, a jedynie dostrzegał uniwersalny wymiar średniowiecznej (scholastycznej) doktryny Kościoła.

Swoją „,naukową”, jak podkreślał Pound, teorię ekonomiczno-społeczną pogłębił podczas pobytu we Włoszech. Wyjechał tam w 1924 r. i przebywał z przerwami (wyjazdy do Stanów Zjednoczonych) do końca II wojny światowej. Osiadł w Rapallo, w Ligurii. Żył wówczas w trójkącie, ze swoją żoną i kochanką Olgą Rudge, dobrze zapowiadającą się skrzypaczką. Pound zamieszkał we Włoszech, kiedy już dyktatura Mussoliniego prawie okrzepła. Poeta marzący o silnej jednostce, która byłaby zdolna „obudzić cywilizację” i zdławić „,rządy światowej, żydowskiej” finansjery, nie ukrywał swojej fascynacji wodzem. Uważał go nie tylko za męża opatrznościowego Włoch, ale i całej Europy. Spotkał się nawet z nim osobiście, podczas specjalnie zorganizowanej audiencji w 1930 r. Pound podarował wówczas dyktatorowi szkic Pieśni XXX, na co ten miał zareagować śmiechem i powiedzieć ,ależ to zabawne!” Pound odczytał to zachowanie w sposób jednoznaczny. Uznał, że Mussolini w pełni rozumie jego poezję i podziela jego poglądy.

„Tajemnic” faszyzmu jednak nie zgłębiał, nie interesowała go szczególnie ani doktryna, ani praktyka polityczna. Faszyzm był dla Pounda przede wszystkim zastrzykiem nowych sił witalnych, reorientował stare wektory polityki w kierunku ożywienia i „renesansu” idei ${ }^{30}$. Owszem imponowała Poundowi organizacja państwa faszystowskiego - jedynowładczego twórcę i dystrybutora, w systemie korporacyjnym dostrzegał zaś namiastki średniowiecznej hierarchii i porządku, ale nic poza tym. Dostrzegał w faszyzmie parareligijny dogmat, który można było zgłębić tylko drogą wolicjonistycznej wiary w „wolę porządku i sprawiedliwości”. Faszystowskie „ukąszenie” w przypadku Ezry Pounda miało, jak

29 Por. E. Pound, Przewodnik po kulturze, przeł. T. Pióro, „Literatura na Świecie” 1995, nr 1-2, s. $97-109$.

30 Por. Ch. Hadjiyiannis, Ezra Pound's Fascist Propaganda 1935-1945, „Journal of Modern Literature" 39, 2015, s. 112-126; N. Zapponi, L'Italia di Ezra Pound, Roma 1976; D. Barnes, Fascist Aesthetics: Ezra Pound's Cutural Negotiations in 1930 Italy, „Jurnal of Modern Literature” 34, 2010, s. 19-35; M. Feldman, Ezra Pound's fascist propaganda 1935-1945, New York 2013; D. Bradshaw, J. Smith, Ezra Pound, James Strachey Barnes ('The Italian Lord Haw-Haw') and Italian Fascism, „Review of English Studies” 64, 2013, s. 672-693; K. Bolton, Ezra Pound, http:// xportal.pl/?p=6804 (dostęp: 16.12.2016). 
się wydaje, podłoże nieodłącznie związane z teorią ekonomiczną, którą głosił, a przede wszystkim z antysemityzmem, którego nie ukrywa ${ }^{31}$. Uważał, że państwo faszystowskie (,łaskawy demiurg”) z duce („pozytywnym bohaterem”) było w stanie zapobiec szatańskim praktykom lichwiarskim i stłumić spisek żydowskiej finansjery.

Rzecz jasna, antysemickie poglądy Pounda w czasach, kiedy je głosił, nie był czymś nowym i nieznanym. Były częścią publicznej debaty. Przy czym szukając jakiejś, choćby uproszczonej, klasyfikacji, można określić Pounda jako antysemitę ekonomicznego, co oczywiście nie może go usprawiedliwiać, a może „rozwodnić" jedynie jego przekonania. Nie może go także usprawiedliwiać rozróżnienie, jakiego dokonywał między „biednymi Żydkami”, dla których był łaskawszy, a bogatymi, którzy - jak sądził - mają przemożny wpływ na losy świata, na co nie raz zwracali uwagę obrońcy poety ${ }^{32}$. Dla nich — jak pisał z ironią Eliot Weinberger - Ezra Pound

nie był antysemitą, posługiwał się Żydami jedynie jako średniowiecznym symbolem lichwy, atakował tylko żydowskich bogaczy — czyż nie protegował Louisa Zukofsky'ego? Pound nie był faszystą: był tylko (niestety) wielbicielem Mussoliniego, który osuszał bagna i wymagał przestrzegania kolejowych rozkładów jazdy. [...] A poza tym był szalony — to znaczy na tyle szalony, by nie być pociągniętym do odpowiedzialności na zdradę ani za swe poglądy na kwestie społeczne, ale nie na tyle, by pozostać uwiezionym przez 12 lat $^{33}$.

W miarę rosnącego od marca 1938 r. napięcia międzynarodowego (Anschluss Austrii) poglądy Ezry Pounda radykalizowały się jeszcze bardziej. Poczuł wiatr

31 Współcześnie do poglądów Ezry Pounda odwołują się niektóre europejskie ruchy nacjonalistyczne i faszystowskie. Za ideowego spadkobiercę uchodzi włoski ruch CasaPound Italia (CPI). Grupa ta, licząca kilka tysięcy członków, powstała w grudniu 2003 r., kiedy włoscy nacjonaliści pod przywództwem Gianluca Iannone zajęli jedną z rzymskich kamienic i założyli tam squat pod nazwą „Casa Pound”. W budynku zamieszkali członkowie ruchu wraz z rodzinami. Znajdowała się tam również biblioteka, studio nagrań, sala konferencyjna i siłownia. CasaPound Italia określa się jako ruch „lewicowego faszyzmu Trzeciego Millenium”. CPI posługuje się symbolem żółwia z motywem czterech strzał zwróconych grotem do środka skorupy. Żółw symbolizuje główny postulat ruchu, tj. prawo każdej włoskiej rodziny do posiadania własnego domu, natomiast strzały — wspólną pracę na rzecz społeczeństwa. W swoim programie odwołuje się do haseł antyemigracyjnych, antysemickich, ekologicznych, proponuje też zmianę konstytucji Włoch (preferuje system autorytarny). Członkowie i sympatycy CasaPound opowiadają się też za budową Zjednoczonych Wolnych i Suwerennych Narodów. W związku z tym krytykują federalistyczny model integracji europejskiej. W kwestiach ustroju społeczno-ekonomicznego pozostaje na pozycjach socjalnych. Ruch patronuje także drużynom sportowym: piłki nożnej, hokeja i rugby. Jest z nim też związanych kilka włoskich zespołów muzycznych. Największym do tej pory sukcesem politycznym było uzyskanie trzech mandatów do rady miejskiej Bolzano. W Polsce CasaPound współpracuje z Narodowym Odrodzeniem Polski i Stowarzyszeniem na Rzecz Kultury i Tradycji „Niklot”. Idee ruchu promują również portale internetowe radykalnej prawicy narodowej, m.in.: Xportal.pl, autonom.pl, nacjonalista.pl, 3droga.pl i cafebabel.pl.

32 H. Berezin, Ezra Pound. Poezja i polityka, „Literatura na Świecie” 1985, nr 1, s. 82.

33 E. Weinberger, Moderniści w piwnicy, a gwiazdy na niebie, „Literatura na Świecie” 1995, nr 1-2, s. 307-308. 
w żagle, jak nigdy dotąd wierzył we własne możliwości politycznych wpływów i dar przekonywania. W 1939 r. wyruszył w ostatnią przed wybuchem wojny podróż do Stanów Zjednoczonych z nadzieją, że uda mu się przekonać amerykańskie elity polityczne do nieangażowania się w konflikt zbrojny. Nikt z poważnych kongresmenów nie chciał jednak rozmawiać z poetą, który żarliwie bronił Mussoliniego i był antysemitą. Za oceanem dobrze pamiętano jego „błyskotliwe” porównania Adolfa Hitlera do Dziewicy Orleańskiej i wygłaszane laudacje pod adresem „duce - męża opatrznościowego w walce ze światowym żydostwem”34. Po powrocie do Włoch, tuż przed wybuchem wojny, jeszcze bardziej utwierdził się w swoim przekonaniu do faszyzmu.

Po przystąpieniu Stanów Zjednoczonych do wojny w 1941 r. Pound uzyskał zgodę Mussoliniego na cykliczne anglojęzyczne audycje radiowe dla „rodaków walczących po niewłaściwej stronie". Oskarżał w nich Żydów o wywołanie wszystkich wojen w historii i nomokrację, czyli zjednoczenie społeczności żydowskiej żyjącej w diasporze, aby rządzić światem. Twierdził, że Żydzi na przestrzeni dziejów posiadali własny system prawny, ale nie znali pojęcia moralności. Zarzut, że Żydzi niepoważnie traktują wykładnię swoich pism, a tym samym istnieją rozbieżności między słowem Tory a ich skłonnościami, pojawiał się oczywiście już w innych tekstach Pounda, jak choćby w broszurze pt. Po co sa pieniadze? (What Is Money For?). Żyd jest dla Pounda ,wiecznym szkodnikiem”, „,bezproduktywnym pasożytem”, niezdolnym do rzeczy wzniosłych. Indywidualistyczne usposobienie Żydów, zawierające geny żeńskie — pisał Pound — wskazuje na niemożność tworzenia i rozwijania kultury ${ }^{35}$.

Robert Casillo wiązał antysemityzm Pounda z fallocentryzmem. Nieprzychylny autorowi Pieśni Eliot Weinberger pisał:

Wedle Pounda obrzezanie uśmierciło fallusa i jest właściwie tożsame z kastracją. Zgadzał się też z Hitlerem, sądzącym, że Żydzi byli pierwszymi nosicielami syfilisu. Wskutek niemoty i schorzałości swych genitaliów Żydzi pozbawieni byli wyobraźni i skazani jedynie na wykorzystywanie swej niewątpliwej inteligencji dla unicestwiającego życie manipulowania władzą, głównie poprzez sprawowanie kontroli finansowej, najbardziej przeciwnej życiu formy panowania $^{36}$.

${ }^{34} \mathrm{Na}$ temat recepcji faszyzmu w Stanach Zjednoczonych pisali V.C. Ferkiss, Ezra Pound and American Fascism, „Journal of Politics” 1955, nr 17, s. 174-195; idem, Populist Influences on American Fascism, „Western Political Quarterly” June 1957, s. 350-370; R. Tokarczyk, Elementy faszyzmu w amerykańskiej myśli politycznej, „Studia nad Faszyzmem i Zbrodniami Hitlerowskimi” IX, 1985, s. 35-65.

35 Eliot Weinberger wyraźnie sugeruje, że Ezra Pound nie stronił również od idei rasistowskich, o czym świadczyć miała jego przyjaźń z chińsko-amerykańskim poetą Davidem Rafaelem Wangiem. Był on zdeklarowanym rasistą, współzałożycielem North American Citizens for the Constitution - organizacji propagującej w USA hasła segregacji rasowej. Por. E. Weinberger, op. cit., s. 309-310.

36 Ibidem, s. 313. Z kolei Marcelyn Pleynet zwracając uwagę na homogeniczność wyrazów: „Ezra” i „Usura” (,lichwa”), przedstawił hipotezę, że obsesja Pounda na punkcie lichwy była w istocie walką z „lustrzanym sobowtórem”. Por. R. Sieburth, op. cit., s. 298-289. 
Jednak głównym, tradycyjnym już zarzutem, jaki autor Pieśni formułuje wobec Żydów, była „konspiracja i nieproduktywność ściśle łącząca się z lichwiarstwem" - pisał Charles Berezin ${ }^{37}$. Mówił to Ezra Pound w momencie, kiedy na oczach wszystkich dokonywała się największa w dziejach zagłada. Nie sposób nie przyznać racji Cezaremu Michalskiemu, który pisał, iż Pound „nie był tylko poetą, ale zbrodniarzem" 38 . Owszem nie uczestniczył bezpośrednio w zagładzie, ale narzędziem zbrodni, w której współuczestniczył, były jego słowa. Nie jest w stanie wizerunku Pounda „ocieplić” stwierdzenie, że nie należy stosować wobec Żydów metod pozaprawnych, a najlepiej byłoby „profilaktycznie wysłać wszystkich „żydłaków”, którzy wywołali wojnę na Wyspę Świętej Heleny, razem z innymi superżydziskami i nieżydowskimi parchami”"39. 4 maja $1942 \mathrm{r}$. ten bodaj najwybitniejszy XX-wieczny pisarz języka angielskiego mówi w eterze:

Stawcie więc dziś czoła komunistom, czy to w wydaniu mongolskim, czy smoluchowatym. Stawcie czoła importowanym Baruchom i Wartburgom, zstąpcie w dolne otchłanie, a poznacie nie tylko Willie'ego Wisemana, któremu przydzielono szefostwo departamentu, lecz nadto staniecie oko w oko z resztą brudnych świń, pragnących zniszczyć muzykę Bacha. Bach? PRECZ. Szekspir? PRECZ. Chcą oni zniszczyć wszystko, co się składa na cywilizację. Fuj z cywilizacją! Żydłak chce tylko władzy. Żydłak, a razem z nim nieposkromione zło, które się skupiło w Londynie od czasów, gdy rząd brytyjski poszczuł czerwonoskórych, by mordowali osadników amerykańskich - a zwłaszcza od czasów, kiedy Londyn otwarcie poszczuł słowiańskie, mongolskie i tatarskie hordy przeciwko Niemcom, przeciwko Polsce, przeciw Finlandii i Rumunii. Bez skrupułów nasyłano zbirów na wszystko to, co w Ameryce godne. Nasłano ich przeciwko dziedzictwu Ameryki. Owszem, ta wojna jest i moją wojną, a toczę ją od 20 lat. Przede mną toczył ją zaś mój dziad ${ }^{40}$.

Nie tonował swoich wypowiedzi, nie przejmował się krytyką nawet w chwili, kiedy wojska alianckie zbliżały się na Półwysep Apeniński. W audycji z 22 kwietnia 1943 r. powiedział:

Powinniście poznać część, przynajmniej cząstkę prawdy o historii swoich sojuszników. Prawdy o Anglii, zrujnowanej przez żydów. O spustoszonej Francji, sparszywiałej pod żydłacką kontrolą i rojącej się od żydów jak od wszy... Nie myślcie sobie, że żydkom zależy na tłumieniu wojen, w których nie-żydzi zabijają się tylko i topią wzajemnie, napędzając dywidend kredytodawcom. Napędzając im nowego kapitału. Część kapitału w postaci kredytów (pewnie już o tym słyszeliście) rzeczywiście znajduje się w żydowskich rękach... Także część amerykańskich dolarów wywędrowała z Ameryki... Przesłał je za granicę nie kto inny jak Heinrick ben Sloman, ben Salomon, ben Izak, ben Morgenthau, syn swojego tatełe. Im dłużej dajecie posłuch tym ludziom, tym mocniej kręcą na was bicz. Słuchajcie dalej synagogicznych pień z jerozolimskich rozgłośni Londynu czy Nowożydojorkowa. Bók z ffami ${ }^{41}$.

37 H. Berezin, Ezra Pound. Poezja i polityka, „Literatura na Świecie” 1985, nr 1, s. 94.

38 C. Michalski, Klatka Ezry, „Arcana” 1999, nr 6, s. 32-39.

39 H. Berezin, op. cit., s. 85.

40 Za C. Michalski, op. cit. Teksty ponad 100 przemówień wygłoszonych przez Ezrę Pounda we włoskim radio można odnaleźć w pracy: Ezra Pound Speaking, red. L.W. Doob, London 1978.

${ }^{41}$ Ibidem. 
Kiedy alianci wkroczyli do Włoch, Pound nie zamilkł. Oskarżał publicznie prezydenta USA o to, że inwazja inspirowana była przez żydowskie lobby. Uparcie przestrzegał przed żydowskim spiskiem, który zagraża światu ${ }^{42}$. Po rozstrzelaniu Mussoliniego i zakończeniu działań wojennych w maju 1945 r. Ezra Pound został złapany niedaleko Genui i pod wojskową eskortą (został przykuty kajdankami do żołnierza armii amerykańskiej oskarżonego o gwałt) przewieziony do siedziby FBA w Genui, gdzie był przesłuchiwany według specjalnych poruszeń J. Edgara Hoovera ${ }^{43}$. Proponował wówczas rządowi Stanów Zjednoczonych pomoc w negocjacjach pokojowych z Japonią. Sugerował, aby łagodnie obejść się z nazistami, wznowić stosunki gospodarcze i polityczne z Włochami oraz zgodzić się na rychłe utworzenie państwa żydowskiego w Palestynie. Wszystkie propozycje Ezry Pounda odrzucono i pod koniec 1945 r. przewieziono go do Komisji Dyscyplinarnej Centrum Szkolenia Armii Stanów Zjednoczonych, niedaleko Pizzy. Został umieszczony w obozie, w stalowej, ażurowej klatce, „sześć na sześć stóp”, oświetlanej przez całą noc reflektorami. Pound spędził tam prawie trzy tygodnie, w całkowitej izolacji, leżąc na betonie, bez środków higienicznych, nie licząc metalowego wiadra na fekalia. W pozostałych klatkach zamknięto zbrodniarzy, morderców i gwałcicieli. Odmawiał wykonywania ćwiczeń, nie rozmawiał z nikim poza kapelanem armii amerykańskiej. Był najpilniej strzeżonym więźniem. Jego klatka nie miała „dachu” chroniącego przed deszczem i słońcem, potrzeby fizjologiczne mógł załatwiać tylko w obecności dwóch strażników. Pomimo zwierzęcych warunków, to tutaj na zwojach papieru toaletowego rozpoczął pisać swoje Pieśnie Pizzańskie (The Pisan Cantos) ${ }^{44}$. Nie wytrzymał upokorzenia i po dwóch i pół tygodnia załamał się. Wyciągnięto go wówczas z klatki i na wniosek obozowego lekarza przeprowadzono wstępne badania psychiatryczne, a następnie przeniesiono go do wojskowego namiotu, zezwalając na dostęp do książek. W listopadzie 1945 r., po niemal półrocznym pobycie w obozie, Pound został przewieziony do Stanów Zjednoczonych i zamknięty w Szpitalu psychiatrycznym św. Elżbiety w Waszyngtonie, gdzie przebywali chorzy psychicznie przestępcy. Jednocześnie rząd amerykański oskarżył Pounda o zdradę stanu i kolaborację z faszystami. Proces jednak się nie odbył. Specjalna komisja lekarska wydała orzeczenie o niepoczytalności Pounda. Stwierdzono u niego chroniczną „manię wielkości” („osobowość narcystyczna”) i uznano, że jest niezdolny do odpowiadania przed sądem ${ }^{45}$.

„Papiery wariata” uratowały mu życie. Poetę zamknięto w specjalnie przygotowanym pokoju bez okien, ze stalowymi drzwiami bez klamek. Dopiero w 1947 r., na wniosek ordynatora szpitala, Ezra Pound został przeniesiony do

42 Zob. również: L.W. Doob, Introduction, [w:] Ezra Pound Speaking, op. cit., s. 5-8.

43 Por. M. de Rachewiltz, [Poprzedniego dnia do Rapallo], przeł. K. Kozioł, „Literatura na Świecie" 1995, nr 1-2, s. 208.

44 L. Engelking, Ezra Pound..., s. 299.

45 K. Wierzyński, Sprawa Ezry Pounda, [w:] idem, Moja prywatna Ameryka, Londyn 1966, s. $175-181$. 
Chestnut Ward, gdzie miał dostęp do biblioteki; mogli go też odwiedzać najbliżsi (żona i przyjaciele). Stanley Kutler, historyk i biograf Ezry Pounda, utrzymuje, iż był on zdrowy psychicznie, a lekarze wydali orzeczenie o jego narcystycznym usposobieniu, chcąc go uchronić przed amerykańskim wymiarem sprawiedliwości. Być może tak było, zważywszy, że ordynator Szpitala św. Elżbiety pozostawał pod urokiem twórczości autora Pieśni ${ }^{46}$.

W miarę upływu czasu sprawa Ezry Pounda nieco przycichła ${ }^{47}$. O jego zwolnienie zabiegali przyjaciele: Ernest Hemingway (laureat literackiej Nagrody Nobla za rok 1954), Thomas Eliot, Eugenio Montale, Robert Frost, Salvatore Quasimodo i Giovanni Papini ${ }^{48}$. Organizowano zbiórki pieniędzy, listy poparcia, w prasie (amerykańskiej, angielskiej i włoskiej) publikowano apele. W 1957 r. prawnik Pounda złożył wniosek o odwołanie aktu oskarżenia przeciwko poecie. 18 kwietnia 1958 r. oskarżenie o zdradę wycofano i z początkiem maja, po 12 latach izolacji, Pound wyszedł na wolność.

Podczas pobytu w „psychuszce” opublikowano nie tylko jego Pieśni Pizzańskie, ale również przekłady Konfucjusza i Sofoklesa. W 1949 r. przyznano mu nawet za Pieśni Pizzańskie prestiżową nagrodę Bollingera ${ }^{49}$. Nie otrzymał jej jednak po proteście jednego z członków jury. Podobnie było w 1972 r., kiedy profesura z Hamilton College zaproponowała, aby przyznać Poundowi Medal Amerykańskiej Akademii Sztuki i Nauki za całokształt twórczości — i wówczas nie obyło się bez skandalu. Pod naciskiem opinii publicznej Rada Akademii wycofała wniosek.

O przyznaniu Poundowi nagrody Bollingera pisała też polska prasa. Przed „polskim październikiem” 1956 r. twórczość Ezry Pounda była „nad Wisłą” w zasadzie prawie nieznana, nie licząc kilku tekstów, jakie opublikowano jeszcze w międzywojniu ${ }^{50}$. Wyróżnienie przyznane Poundowi traktowano jako przejaw zdegenerowania demokracji, nie rozumiano też zupełnie „metody”, jaką stosował poeta. „Trybuna Robotnicza” pisała np.:

Pewien amerykański poeta napisał poemat, który, jak donoszą, składa się nie tylko z kombinacji, niezrozumiałych angielskich słów, lecz także z chińskich liter, nut muzycznych, pisma greckiego, liczb, słów łacińskich, francuskich i niemieckiej gwary, amerykańskiego i żydowskiego dialektu oraz specjalnie dobranych fonetycznych dźwięków ${ }^{51}$.

46 E. Weinberger, op. cit., s. 309.

47 A. Baranowska, Nota, „Twórczość” 1974, nr 9, s. 163-164.

48 Ernest Hemingway twierdził, że Ezra Pound był pisarzem wspaniałomyślnym i bezinteresownym. „Pomagał poetom, malarzom, rzeźbiarzom, w których wierzył, i pomógłby każdemu, kto był w kłopocie, czy wierzył w niego, czy nie” (za E. Hemingway, Ezra Pound i jego bel esprit, [w:] idem, Ruchome święto, przeł. B. Zieliński, Warszawa 1966, s. 85).

49 Poetycka nagroda Bollingera — amerykańska nagroda literacka, obecnie przyznawana przez Beinecke Library Yale University za książkę poetycką amerykańskiego twórcy.

50 Zob. np. S. Helsztyński, Ezra Pound i T.S. Eliot, „Wiadomości Literackie” 1931, nr 10, s. 2; idem, Od Szekspira do Joyce'a, Warszawa 1939, s. 295-296.

51 Por. D.G., H.D., Trubadur ,, zachodniej kultury”, „Trybuna Robotnicza” 1949, nr 58, s. 8. 
Jest oczywistym fakt, że „przypadek Ezry Pounda” stał się doskonałą okazją do przepuszczenia ataku na zwulgaryzowaną, pełną fałszu kulturę kapitalistyczną (burżuazyjną), skoro amerykańska „sfora szakali” przyznała nagrodę faszyście, ratując go tym samym przed procesem sądowym ${ }^{52}$.

Nieco więcej zrozumienia wykazano wobec Pounda dopiero po umorzeniu jego sprawy w 1958 r. Tygodnik „Orka” przemilczał nawet jego antysemityzm i flirt z faszyzmem, pisząc, iż autor Pieśni był zdeklarowanym pacyfistą, który tuż po zakończeniu wojny wystosował apel do żołnierzy amerykańskich o porzucenie służby wojskowej ${ }^{53}$. Tak czy inaczej, dopiero po śmierci Pounda w 1972 r. zainteresowano się jego biografią i twórczością na poważnie, publikując teksty krytycznoliterackie, wiersze, fragmenty poematów, esejów i oczywiście pieśni ${ }^{54}$.

W lipcu 1958 r. Ezra Pound dotarł do Włoch. Witał swoją „drugą ojczyznę” w geście rzymskiego salutu. Osiadł tutaj na stałe. Zamieszkał w zamku swojego zięcia Borisa de Rachewiltz we włoskim Tyrolu. Jego przekłady, tłumaczenia, poezje i eseje (w całości i we fragmentach) ukazały się Stanach Zjednoczonych i niemal wszystkich państwach europejskich. W 1963 r. Academy of American Poets przyznała mu specjalną nagrodę, w uznaniu dla jego twórczości. Również w tym czasie Pound sporo podróżował — odwiedzał Stany Zjednoczone, Wielką Brytanię, w 1965 r. uczestniczył w Londynie w mszy żałobnej w intencji Thomasa Eliota.

Pound nie zerwał ze swoimi poglądami politycznymi. Dopiero na kilka lat przed śmiercią uznał je za błąd. „W chwilach załamania [Pound cierpiał na depresję — T.S.]” — pisał Leszek Engelking — „zdawał się przekonany, że zmarnował życie" ${ }^{55} .1$ listopada 1972 r. umarł w Wenecji. Do końca pozostała z nim Olga Rudge. Został pochowany na cmentarzu, na wyspie San Michele, zaledwie kilka kwater od grobu Igora Strawinskiego i Siergieja Pawłowicza Diagilewa.

52 Zob. np. Dr Panfil, Awantura o nagrodę, „Odrodzenie” 1949, nr 39, s. 6; Z. Kałużyński (Z.K.), „Trybuna Literacka” 1958, nr 20, s. 2; Tadeusz Różewicz w wierszu pt. Równina nazwał Pounda „zdrajcą”, zob. T. Różewicz, Poezje wybrane, Wrocław 1971, s. 268-269.

53 Ezra Pound jeden z najwybitniejszych poetów amerykańskich, „Orka” 1958, nr 19, s. 8.

54 Zob. L. Engelking, Twórczość Ezry Pounda, „Literatura na Świecie” 1985, nr 1, s. 227-264. Spośród polskich edycji dzieł E. Pounda na uwagę zasługują zwłaszcza: Duch romański, Warszawa 1999; Liryki najpiękniejsze, wstęp J. Kapica, przeł. L. Engelking, J. Niemojewski, Warszawa 2000; Maska i pieśń: antologia poezji, przeł. J. Niemojewski, Monachium 1960; Pieśni, przeł. L. Engelking, K. Kozioł, A. Sosnowski, A. Szuba, Warszawa 1996; Pieśni, przeł. L. Engelking, Warszawa 1999; Pieśni, wyb. i połowie A. Sosnowski, przeł. L. Engelking, K. Kozioł, A. Sosnowski, Warszawa 1966; Poezja, wyb., wstęp i przekład J. Niemojewski, Warszawa 1993; Poezje wybrane, wyb., wstęp i przekład L. Engelking, Warszawa 1989; Sztuka, maszyny i inne pisma, przeł. E. Mikina, Warszawa 2003; Wiersze, poematy i Pieśni, wyb., wstęp i przekład L. Engelking, Warszawa 2012.

55 L. Engelking, Ezra Pound..., s. 299. 


\section{Bibliografia}

\section{1. Źródła}

\section{Publicystyka, krytyka literacka}

Berezin H., Ezra Pound. Poezja i polityka, „Literatura na Świecie” 1985, nr 1.

Curruth K., Poezja Ezry Pounda, przeł. Z. Bohdanowicz, „Tematy” 1962, nr 2.

D.G., H.D., Trubadur ,zachodniej kultury”, „Trybuna Robotnicza” 1949, nr 58.

Engelking L., Imagizm, „Literatura na Świecie” 1991, nr 1.

Engelking L., Maski Ezry Pounda, „Literatura na Świecie” 1980, nr 4.

Ezra Pound jeden z najwybitniejszych poetów amerykańskich, „Orka” 1958, nr 19.

Flint F.S., E. Pound, Imagisme, przeł. L. Engelking, „Literatura na Świecie” 1991, nr 1.

Helsztyński S., Ezra Pound i T. S. Eliot, „Wiadomości Literackie” 1931, nr 10.

Helsztyński S., Od Szekspira do Joyce'a, Warszawa 1939.

Helsztyński S., Wprowadzenie do Ezry Pounda, [w:] idem, Od Chaucera do Ezry Pounda, Warszawa 1976.

Hemingway E., Ezra Pound i jego bel esprit, [w:] idem, Ruchome święto, przeł. B. Zieliński, Warszawa 1966.

K.Z. (Kałużyński Z.), [brak tytułu], „Trybuna Literacka” 1958, nr 20.

Kubiak Z., Dialog Eliota z Poundem, „Tygodnik Powszechny” 1973, nr 21.

Michalski C., Klatka Ezry, „Arcana” 1999, nr 6.

Mozgol R., Nie burzycielami być, lecz ludźmi. Poezja Ezry Pounda, „Zawsze Wierni” 2002, nr 2 (45).

Panfil dr., Awantura o nagrodę, „Odrodzenie” 1949, nr 39.

Pióro T., Przewodnik po Poundzie, „Literatura na Świecie” 1995, nr 1-2.

Russel P., Ezra Pound, przeł. M. Niemojewska, „Poezja” 1970, nr 3.

Sieburth R., Ezra Pound: Ekonomia poezji/Poezja ekonomii, „Literatura na Świecie” 1995, nr 1-2.

Wierzyński K., Sprawa Ezry Pounda, [w:] idem, Moja prywatna Ameryka, Londyn 1966.

Wróbel Ł., Stowa i obrazy. O poezji Ezry Pounda, „Kultura Liberalna” 2012, nr 194.

Wspomnienia, pamiętniki, relacje

Hall D., Wywiad z Ezra Poundem, „Literatura na Świecie” 1985, nr 1.

Ezra Pound Speaking, red. L.W. Doob, London 1978.

Rachewiltz M. de, [Poprzedniego dnia do Rapallo], przeł. K. Kozioł, „Literatura na Świecie” 1995, nr $1-2$.

\section{Prace Ezry Pounda (wiersze, poematy, pieśni, eseje i pisma)}

Pound E., Duch romański, przeł. L. Engleking, Warszawa 1999.

Pound E., Liryki najpiękniejsze, wstęp J. Kapica, przeł. L. Engelking, J. Niemojewski, Warszawa 2000.

Pound E., Maska i pieśń: antologia poezji, przeł. J. Niemojewski, Monachium 1960. 
Pound E., Pieśni, wyb. i połowie A. Sosnowski, przeł. L. Engelking, K. Kozioł, A. Sosnowski, Warszawa 1966.

Pound E., Pieśni, przeł. L. Engelking, K. Kozioł, A. Sosnowski, A. Szuba, Warszawa 1996.

Pound E., Pieśni, przeł. L. Engelking, Warszawa 1999.

Pound E., Poezja, wyb., wstęp i przekład J. Niemojewski, Warszawa 1993.

Pound E., Poezje wybrane, wyb., wstęp i przekład L. Engelking, Warszawa 1989.

Pound E., Przewodnik po kulturze, przeł. T. Pióro, „Literatura na Świecie” 1995, nr 1-2.

Pound E., Rzut oka za siebie, przeł. L. Engelking, „Literatura na Świecie” 1985, nr 1.

Pound E., Sztuka, maszyny i inne pisma, przeł. E. Mikina, Warszawa 2003.

Pound E., Wiersze, poematy i Pieśni, wyb., wstęp i przekład L. Engelking, Warszawa 2012.

Pound E., Wortycyzm (fragment), przeł. L. Engelking, „Literatura na Świecie” 1991, nr 1.

\section{Opracowania}

Arno A., Bład trubadura, http://www.dwutygodnik.com/artykul/3088-blad-trubadura.html.

Baranowska A., Ezra Pound (30 X 1885 - 1 IX 1972), „Twórczość” 1973, nr 4.

Baranowska A., Historia pewnego mecenatu, „Twórczość” 1968, nr 7.

Baranowska A., Nota, „Twórczość” 1974, nr 9.

Barnes D., Fascist Aesthetics: Ezra Pound's Cutural Negotiations in 1930 Italy, „Jurnal of Modern Literature" 34, 2010.

Bolton K., Ezra Pound, http://xportal.pl/?p=6804.

Bradshaw D., Smith J., Ezra Pound, James Strachey Barnes ('The Italian Lord Haw-Haw') and Italian Fascism, „Review of English Studies” 64, 2013.

Brody P., Exspatriate. A Biography of Ezra Pound, Oxford 2014.

Brooks W. van, Fenollosa and His Circle, with Other Essays in Biography, New York 1962.

Butor M., Poetycka próba Ezry Pounda, „Literatura na Świecie” 1985, nr 1.

Chisolm L.W., Fenollosa: the Far East and American Culture, New Haven 1963.

Doob L.W., Introduction, [w:] Ezra Pound Speaking, red. L.W. Doob, London 1978.

Eliot T.S., Ze wstęu do „Poezji wybranych” Ezry Pounda [1928], „Literatura na Świecie” 1985, nr 1.

Eliot T.S., Ze wstępu do tomu „Literary Esseys of Ezra Pound” [1954], przeł. L. Engelking, „Literatura na Świecie" 1985, nr 1.

Engelking L., Ezra Pound, „Literatura na Świecie” 1985, nr 1.

Engelking L., Kalendarium życia i twórczości Ezry Pounda, „Literatura na Świecie” 1985, nr 1.

Engelking L., Owoc młodzieńczej miłości, [w:] E. Pound, Duch romański, Warszawa 1999.

Engelking L., Posłowie, [w:] E. Pound, Wiersze, poematy i pieśni, przeł. L. Engelking, Wrocław 2012.

Feldman M., Ezra Pound's fascist propaganda 1935-1945, New York 2013.

Ferkiss V.C., Ezra Pound and American Fascism, „Journal of Politics”1955, nr 17.

Ferkiss V.C., Populist Influences on American Fascism, „Western Political Quarterly” June 1957.

Fraser G.S., Ezra Pound, London 1960.

Hadjiyiannis Ch., Ezra Pound's Fascist Propaganda 1935-1945, „Journal of Modern Literature” 39, 2015.

Hutnikiewicz A., Od czystej formy do literatury faktu, Torun 1965.

I.K. (Iłłakowiczówna K.), Ezra Pound, „Poezja” 1968, nr 12.

Jones P., Introduction, [w:] Imagist Poetry, red. P. Jones, Harmondswort 1976.

Kenner H., Niejasność, przeł. Artur Zapałowski, „Literatura na Świecie” 1995, nr 1-2.

Kenner H., The Poetry of Ezra Pound, New York 1951;

Łąbędzka I., Chiny Ezry Pounda, Poznań 1998.

Marcinkiewicz P., Miłosz a amerykańska awangarda: od Pounda do Ashbery'ego, „Przekładaniec” 2011, nr 25 .

Studia nad Autorytaryzmem i Totalitaryzmem 38, nr 3, 2016

(C) for this edition by CNS 
Martin-Nielsen J., An Engineer's View of an Ideal Society: The Economic Reforms of C.H. Douglas (1916-1920), „Spontaneous Generations” 1, 2007.

Miner E., Pound, haiku i obraz poetycki, przeł. L. Engelking, „Literatura na Świecie” 1985, nr 1.

Moody A.D., Ezra Pound Poet: A Portrait of the Man and His Work, t. II. The Epic Years 19211939, Oxford 2014.

Moody A.D., Ezra Pound Poet: A Portrait of the Man and His Work, t. III. The Epic Years 19391972, Oxford 2015.

Morrison P., The Poetics of Fascism. Ezra Pound, Thomas S. Eliot, Paul de Mann, Oxford 1996.

Mullins E.C. Jr., This Difficult Individual: Ezra Pound, Los Angeles 1961.

Norman Ch., Ezra Pound, New York 1960.

Perloff M., Gaudier-Brzeska. Ezry Pounda portret artysty jako tekst — kolaż, „Literatura na Świecie” 1985, nr 1.

Pietrzak W., Poezja życia/poezja instrukcji: poems Andrzeja Sosnowskiego w kontekście teorii poezji Ezry Pounda, „Poznańskie Studia Polonistyczne: Seria Literacka”, nr 42.

Rosenthal M.L., Pieśni Ezry Pounda, przeł. A. Sylwanowicz, „Literatura na Świecie” 1985, nr 1.

Sato K., Czy można przesadzić kwiat rzepaku? (Japońskie haiku i ruch haiku na Zachodzie), przeł. A Szuba, „Literatura na Świecie” 1991, nr 1.

Schmied W., Ezra Pound: ein Leben zwischen Kunst und Politik. Essays, Innsbruck 1994.

Sosnowski A., Postowie, [w:] E. Pound, Pieśni, przeł. L. Engelking et al., Warszawa 1996.

Sosnowski A., Z genealogii modernizmu: poezja trzeciego nieba, „Literatura na Świecie” 1995, nr 1-2.

Szymańska K., Ezra Pound o wielu twarzach (E. Pound, Wiersze, poematy, pieśni, przeł. L. Engelking), „Literatki”, 28.06.2012 r., http://literatki.com/6566/ezra-pound-wiersze-poematy-ipiesni-ezra-pound-o-wielu-twarzach.

Tokarczyk R., Elementy faszyzmu w amerykańskiej myśli politycznej, „Studia nad Faszyzmem i Zbrodniami Hitlerowskimi" IX, 1985.

Waluty, Pracy $i$ dyskwalifikacja (Ezra Pound), http://thule-italia.com/wordpress/valuta-lavoro-edecadenze-ezra-pound-prima-parte/?lang=pl.

Wącior S., Modernist Mutations - The Morphology of the Imagist Poem: Context - Text - Intertext, Lublin 2003.

Zapponi N., L'Italia di Ezra Pound, Roma 1976.

\section{„EZRA’S CAGE”. BETWEEN POETRY AND POLITICS}

\section{Summary}

Ezra Pound (1885-1975) was, next to Thomas Stearns Eliot, the most prominent American poet of modernist. He was considered the creator of vorticism and imagism - modern trends in art and world culture. In his works he reached to different eras and cultural trends. He was as well fascinated by medieval Provençal, Spanish and Italian literature, and Japanese art of haiku. On his work also had an impact scholasticism, Confucianism and Far East literature. In addition to poetry, Pound was also involved in literary criticism, painting and sculpture, he wrote historiosophical essays and dramas. The greatest fame brought him, however, written for many years, „Canto”. During his stay in the British Isles he also dealt with politics and economics. He was considered a supporter of the theory of Social Credit of Hugh Douglas Clifford, a British engineer and economic theorist. In the early twenties Pound went to Italy. Here he became fascinated with fascism and the person of Benitto Musollini. In his works (including his poetic works) appeared clear fascist and anti-Semitic accents. He criticized Jewish international financiers and banking (critique of usury). During World War II he gave propaganda "talks" in the Italian radio. He praised the organization of the fascist state and fascism as an idea, and at the same time warned the threat from international Jewish conspiracy. 
His views meant that he was accused of collaboration and treason. He was arrested and imprisoned in the US prison camp near Genoa. He spent almost a month in a closed cage. During his stay in the camp he had nervous breakdown. After transportation to the United States for many years he was locked out in hospital for mentally ill. After leaving the hospital, he returned to public space. Still creative, he was nominated for the most prestigious literary awards. His works have been translated into many languages around the world, including Polish. He died in Italy in 1975.

Keywords: Fascism, anti-Semitic, Ideology and literature, Culture, Economy.

Tomasz Sikorski

t.sikorski@poczta.fm 